\title{
SOUTHERN BLUEFIN TUNA IN THE INDONESIAN LONGLINE FISHERY: Historical DEVElopment, Compostrion, SEASON, SOME Biological Parameters, LANDING Estimation AND CATCH STATISTICS FOR 1993
}

\author{
Tim Davis ${ }^{*}$ ), Sofri Bahar $\left.{ }^{* 4}\right)$ and Jessica Farley ${ }^{*}$ )
}

\begin{abstract}
The longline fishery based in Bali has expanded rapidly in recent years: 291 vessels, mainly of Taiwanese origin, operated out of Benoa in 1993. Tuna caught for the fresh sashimi market are exported through Ngurah Rai Airport in Bali to Japan, Hawaii, California, Singapore, Hong Kong and France. Catches in 1993 were monitored at one of four companies processing tuna for export. Yellowfin tuna $(52.7 \%)$ dominated the catch, followed by bigeye tuna $(31.3 \%)$, albacore $(3.8 \%)$, billfish $(3.6 \%)$, southern bluefin tuna $(3.1 \%)$ and others $(0.9 \%)$. The total longline catch of tuna landed in Bali in 1993 was estimated to be 24800 tonnes. The largest catches of southern bluefin tuna were in January, with the estimated 765 tonnes of southern bluefin tuna, 498 tonnes were exported, with negligible catches from May to August. The dressed weight of southern bluefin tuna ranged from 55 to $170 \mathrm{~kg}$ with a mean of $103 \mathrm{~kg}$. The lengths ranged from 164 to $199 \mathrm{~cm}$ with a mean of $187 \mathrm{~cm}$.
\end{abstract}

KEYWORDS: Southern bluefin tuna, Thunnus maccoyii, longline tuna, Indonesia, Bali

\section{Introduction}

The tuna resources in Indonesian waters have not been fully utilised in the past. The tuna fishery expanded when foreign tuna longline vessels were allowed to operate in Indonesian waters on payment of a fishing fee or by jointly operating with private Indonesian companies. Since 1985 the high demand for fresh tuna, especially by Japan, has resulted in rapid expansion of longline fishing and a dramatic increase in catches of tuna. Southern bluefin tuna, while a small part of the tuna catch, are landed in significant quantities relative to the world-wide fishery for this species. The Indonesian fishery catches adult southern bluefin tuna that migrate to the fishing grounds to spawn. As southern bluefin tuna stocks are considered to be over-exploited, and parental stocks in particular are depleted (Anon. 1994, Caton et al., 1990), it is important that these catches are monitored. As a consequence, a joint research program was set up by the Commonwealth Scientific and Industrial Research Organisation (CSIRO) Australia and the Research Institute for Marine Fisheries (RIMF) Indonesia in September 1992 to monitor the catches of southern bluefin tuna in the longline fishery. Initially landings at Muara Baru,

\footnotetext{
") CSIRO Division of Fisheries, Marine Laboratories GPO Box 1538, Tasmania 7001, Australia

"n) Reseacher at Research Institute for Marine Fisheries, Jakarta
} 
Java and Benoa, Bali were monitored. However, as few southern bluefin tuna were landed in Muara Baru, and because there had been a shift in fleet operations from Muara Baru to Benoa, landings are now only monitored at Benoa. All landings by fishing companies processing tuna at PT. Perikanan Samodra Besar in Benoa have been monitored. This is one of four companies processing tuna for export in Bali. This paper provides a historical perspective of the longline fishery, its development in Bali and the results of catch monitoring of tuna processed at PT. Perikanan Samodra Besar (PSB) in 1993.

\section{Materials and Methods}

\section{Catch Sampling}

All tuna landings at PSB were monitored and the total weight and number of tuna by species and export status was recorded. Any southern bluefin tuna (SBT) were individually weighed and, if possible their lengths were measured. A total of 1208 SBT were processed at PSB in 1993. All of these fish were weighed and dressed (gutted, gilled, fins removed and tail stock intact), and the fork lengths of 899 SBT were measured. Other biological data such as gonad weights and otoliths were also collected.

\section{Catch Volume}

The total landing of SBT at Benoa (Bali) was determined by using the ratio of exported to total SBT processed by PSB and extra polating that to total landings by all processors.

\section{Fishing Ground}

The positions of SBT catches were compiled from daily reports from PSB fishing boats during three years from 1991-1993.

\section{Results and Discussions}

\section{Historical Development of the Longline Fishery}

PT. Perikanan Samodra Besar (PSB) became the first national tuna company in Indonesia to longline for tuna when it began operations in the Indian Ocean off the west coast of Sumatra at Sabang in 1972. It expanded its operations to the Indian Ocean off the Lesser Sunda Islands in 1974, and in 1977 shifted its base to Benoa, Bali. Yellowfin tuna was the main species caught between 1978 
Davis, T.; Bahar, S. and Farley, J.

and 1991 (Table 1). About 20 vessels fished up to 1985, but when low tuna prices and high fuel costs forced the company to limit effort to 5 vessels, they only fished from October to December in 1986. Since then, the price of fresh tuna exports has risen. Although 13 vessels were available for fishing, the high costs of fuel and maintenance of the ageing fleet limited PSB's operations to about 7 vessels. At the same time, it expanded its operations to process tuna landed by other companies for export. Since 1992, PSB has targeted bigeye tuna (BET) resulting in lowered catches overall but with a high proportion of bigeye $(>80 \%)$. SBT continue to be a very small part of the catch: between 0.1 and $0.7 \%$.

Table 1. Catch composition of tuna caught by longline by PT. Perikanan samodra besar for the years 1978-1993.

\begin{tabular}{|c|c|c|c|c|c|c|c|c|c|}
\hline \multirow{2}{*}{ Year } & \multicolumn{2}{|c|}{ Yellowfin } & \multicolumn{2}{|c|}{ Bigeye } & \multicolumn{2}{|c|}{ Albacore } & \multicolumn{2}{|c|}{ Southern bluefin } & \multirow{2}{*}{$\begin{array}{l}\text { Total } \\
\text { Tonnes }\end{array}$} \\
\hline & Tonnes & Percent & Tonnes & Percent & Tonnes & Percent & Tonnes & Percent & \\
\hline 1978 & 1215.7 & 66.9 & 395.8 & 21.8 & 202.2 & 11.1 & 4.0 & 0.2 & 1817.7 \\
\hline 1979 & 1273.9 & 67.4 & 371.5 & 19.7 & 235.9 & 12.4 & 9.7 & 0.5 & 1891.0 \\
\hline 1980 & 1478.0 & 72.9 & 367.2 & 18.1 & 173.3 & 8.7 & 7.9 & 0.3 & 2025.5 \\
\hline 1981 & 1806.3 & 79.4 & 319.8 & 14.0 & 147.6 & 6.5 & 2.7 & 0.1 & 2276.4 \\
\hline 1982 & 1847.9 & 76.4 & 426.6 & 17.6 & 142.5 & 5.9 & 2.2 & 0.1 & 2419.2 \\
\hline 1983 & 1024.5 & 69.6 & 200.2 & 13.6 & 245.2 & 16.6 & 2.8 & 0.2 & 1472.7 \\
\hline 1984 & 1641.2 & 85.2 & 230.3 & 11.9 & 54.1 & 2.8 & 1.3 & 0.1 & 1926.9 \\
\hline 1985 & 1383.7 & 80.5 & 288.3 & 16.8 & 43.7 & 2.5 & 4.0 & 0.2 & 1719.7 \\
\hline 1986 & & \multicolumn{8}{|c|}{ Data not available } \\
\hline 1987 & 905 & 54.7 & 455.3 & 27.4 & 293.1 & 17.7 & 2.7 & 0.2 & 1656.1 \\
\hline 1988 & 575.9 & 53.8 & 364.5 & 34.0 & 126.1 & 12.0 & 3 & 0.2 & 1069.1 \\
\hline 1989 & 428.2 & 34.7 & 526.9 & 42.7 & 94.5 & 7.7 & 8.4 & 0.7 & 1234.9 \\
\hline 1990 & 412.2 & 50.4 & 264.4 & 32.4 & 136.6 & 16.7 & 3.5 & 0.4 & 816.7 \\
\hline 1991 & 289.2 & 65.1 & 106.3 & 24.0 & 46.1 & 10.4 & 2.1 & 0.5 & 443.7 \\
\hline 1992 & 91.6 & 13.7 & 540.7 & 81.0 & 31.3 & 4.7 & 3.6 & 0.5 & 667.2 \\
\hline 1993 & 60.1 & 9.2 & 529.3 & 81.4 & 56.6 & 8.7 & 4.2 & 0.7 & 650.1 \\
\hline
\end{tabular}

Source: PT. Perikanan Samodra Besar Cabang Benoa, Bali 
The shift of longline effort to the fresh sashimi export market, and the sub sequent relocation to Benoa of the sector of the fleet catching SBT have simplified the monitoring of the SBT fishery. Previously, southern bluefin tuna were brought to Muara Baru, Jakarta, as a frozen product which was mostly transhipped overseas without processing. This meant that tuna were not landed and hence available for inspection and documentation. Longliners with the capacity to freeze catches could stay at sea for long periods and hence access the SBT grounds of the Indonesian Exclusive Economic Zone and the high seas. At present, virtually all SBT caught by Indonesian-based fisheries is landed fresh at Benoa because this port is close to the fishing grounds. This facilitates monitoring.

The shift of longline operations from Muara Baru to Benoa has been largely responsible for the dramatic increase in the longline fleet and tuna landings in Bali in recent years. Few vessels of this type are still operating out of Muara Baru so the influx of vessels to Benoa will slow in future, unless more vessels relocate from Taiwan.

\section{- Fishing grounds}

There are two major longline grounds in the Indian Ocean fished by Indonesian-based fleets: southwest of Central Java extending to West Sumatra (landings at Port Muara Baru, Jakarta); and southeast to East Timor (landings at Port Benoa, Bali) (Figure 1). SBT are caught on the latter ground. Japanese, Korean and Taiwanese longliners formerly fished this ground and froze their tuna catches. After 1987, effort by these countries was greatly reduced as the fresh tuna fishery developed. Data provided by PSB on the position of longline sets that included SBT catches for the years 1991 to 1993 indicate that they were mainly caught on the central part of this fishing ground, although they have been caught as far east as Timor (Figure 2). SBT have been caught very near the coast off Cempi Bay, Sumbawa.

\section{- Longline fishing fleet}

The fishing fleet operating out of the Port of Benoa, Bali has built up rapidly in recent years (Figure 3). This has been due to the influx of Indonesian-flagged longline boats of Taiwanese origin. In 1993, 291 longline boats owned by 21 companies operated out of Benoa. Benoa is the closest port in the region with access to an international airport (Ngurah Rai Airport, Bali) which is important, as most longline tuna catches are exported to the fresh sashimi markets of the world. The fresh export market has also been the stimulus for a steady exodus of vessels previously based at Muara Baru, Jakarta, 
Davis, T.; Babar, S. and Farley, J.

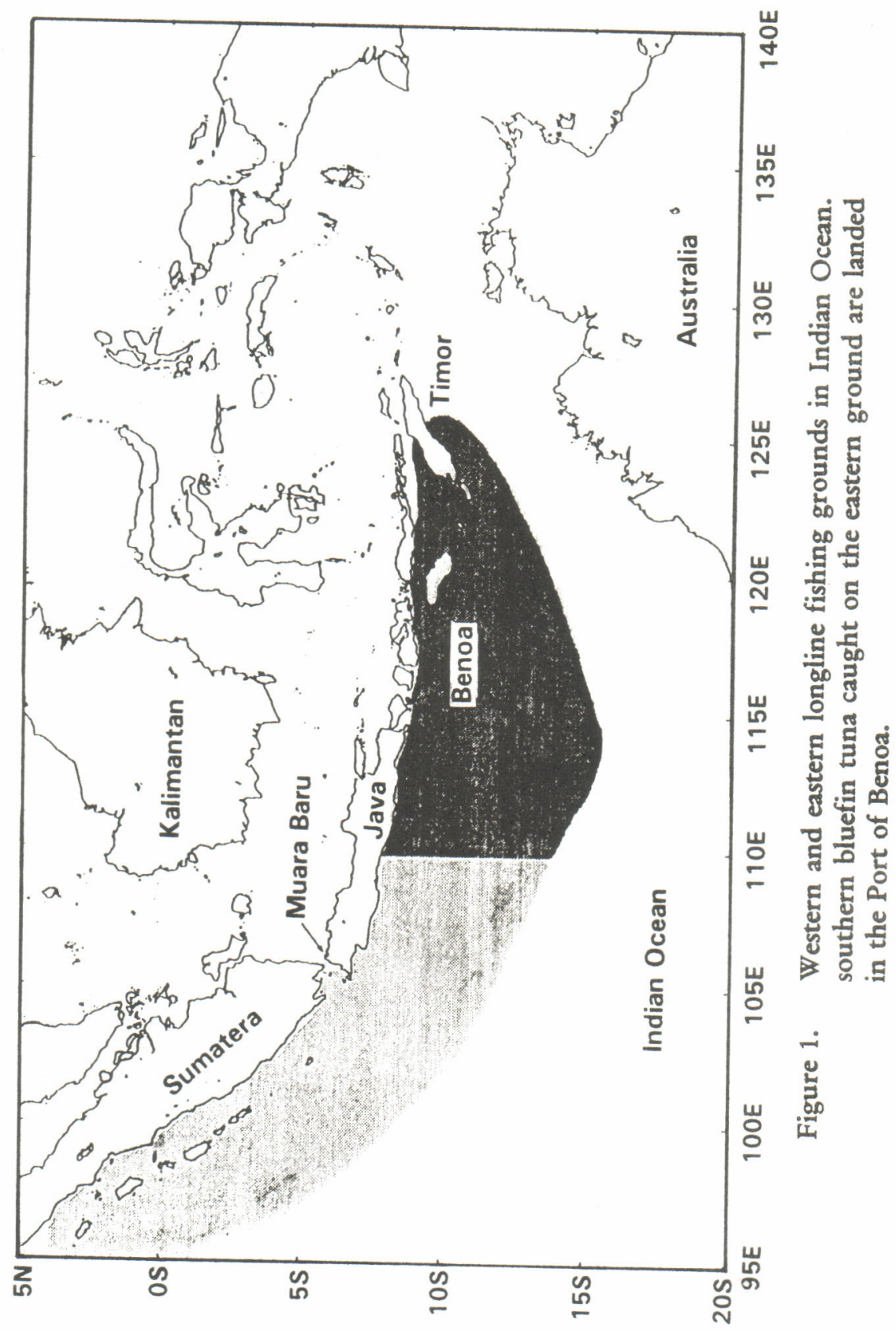


IFR Journal 1(1), 1995

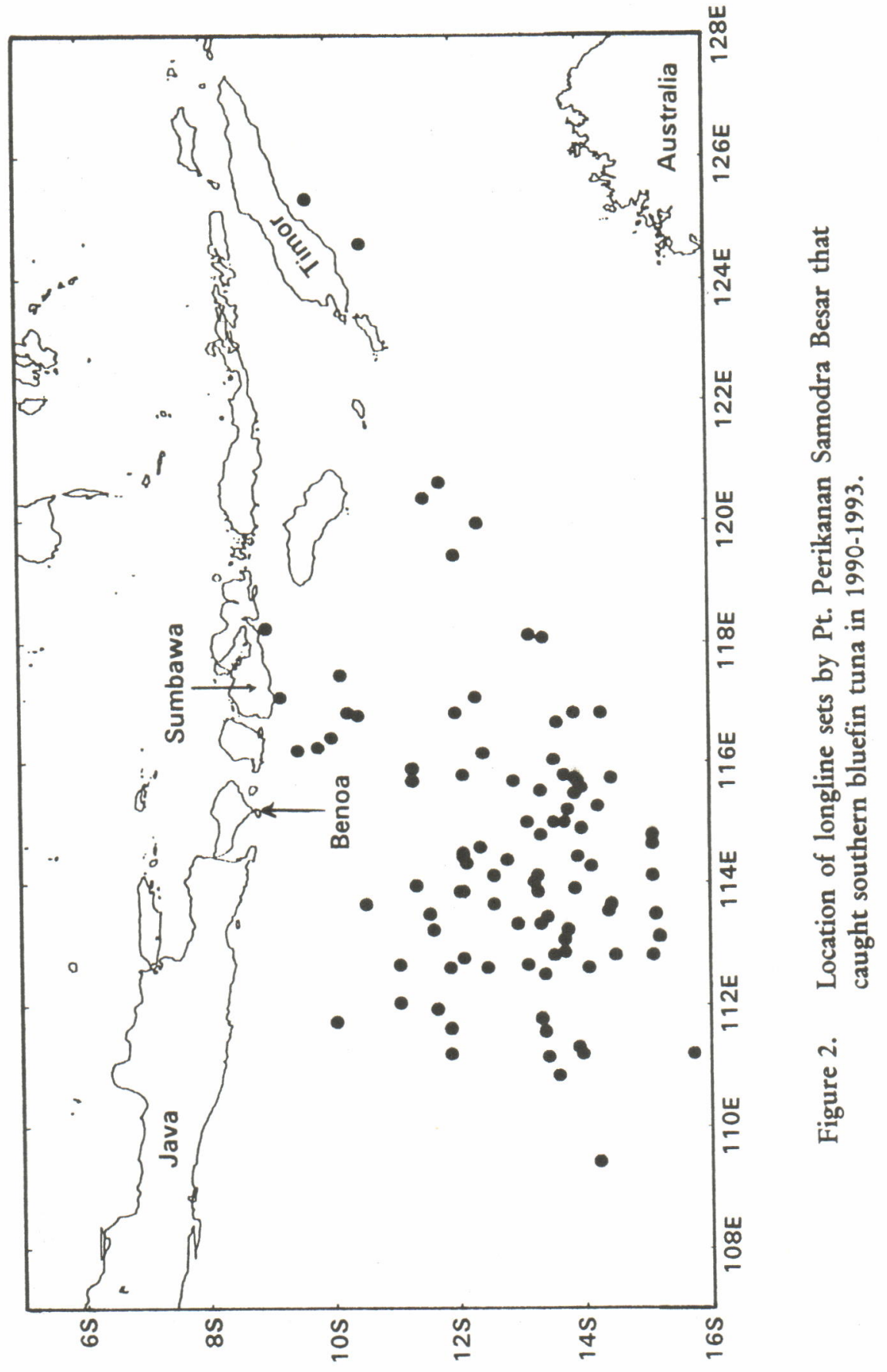


Davis, T.; Bahar, S. and Farley, J.

to Benoa which is closer to the longline grounds. Tuna exports through Ngurah Rai Airport, Bali have increased dramatically, matching the influx of longline vessels operating out of Benoa (Table 2).

Table 2. Export of tuna from Bali 1988-1993.

Unit : tones

\begin{tabular}{rcccc}
\hline Year & Fresh tuna & Frozen tuna & Percent fresh & Total tuna \\
\hline 1988 & 1284.9 & 881.1 & 59 & 2166.0 \\
1989 & 3796.1 & 3041.9 & 56 & 6838.0 \\
1990 & 3636.6 & 2585.6 & 58 & 6222.2 \\
1991 & 7739.3 & 1387.8 & 85 & 9127.1 \\
1992 & 12084.4 & 2740.5 & 82 & 14824.9 \\
1993 & 12582.1 & 4129.3 & 75 & 16711.4 \\
\hline Resources: & $\begin{array}{l}\text { Provincial Fisheries Service of Bali, Laboratory Quality Control and Fish Inspection, Directorate } \\
\end{array}$
\end{tabular}

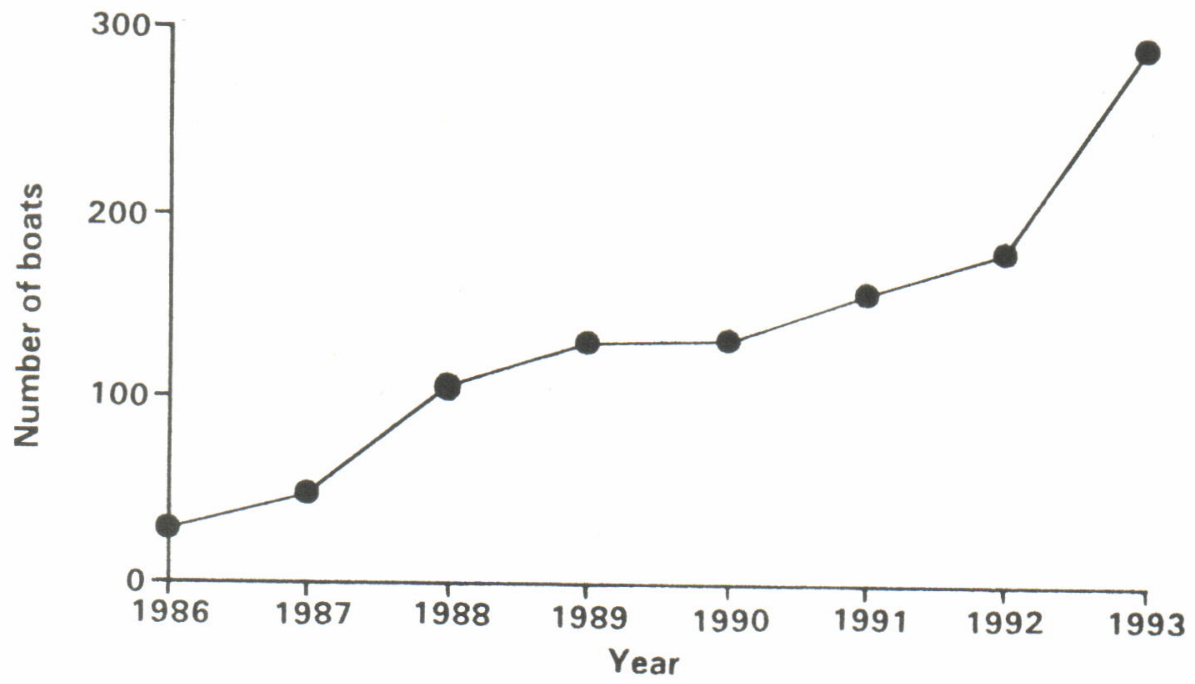

Figure 3. Number of longline vessels operating out of the Port of Benoa between 1986-1993.

Three types of boats operate in the longline fishery: mini-longline, regular (Taiwanese) longline and deep longline. Mini-longline boats are less than 20 tonnes gross weight, have 6-8 crew, and fish for about 10-14 days per trip. The boats are not equipped with electronic navigational aids. They use monofilament main lines 27-33 km long, and 4-6 branch lines with 400-600 hooks, 
which fish at depths of $50-180 \mathrm{~m}$. Milkfish from East Java is most commonly used as live bait and squid, milkfish and Decapterus spp. as frozen baits. Regular longline boats of 20-50 tonnes gross weight with 10-12 crew, fishing for about 10-20 days per trip, are the most common type of boat in the fishery (Figure 4). They use the Taiwanese style of longline fishing with monofilament main lines of $37-40 \mathrm{~km}$ length and 4-6 branch lines with 700-1200 hooks, which fish at depths of 50-220 m. The boats are equipped with GPS, echosounder and SSB radio, and radio buoys are attached to the longlines. Live milkfish supplied from farms in Lamongan and Surabaya (East Java) are generally used as bait. The use of live bait rather than frozen bait increases the hook rate for yellowfin tuna 2-4 times. However, during the full moon tuna appear to feed at greater depths, so frozen baits are used to facilitate deeper sets, which also catch a greater proportion of bigeye tuna. Deep longline boats are generally larger than 50 tonnes gross weight, have $15-18 \mathrm{crew}$ and make fishing trips of 10-14 days. They use the Japanese autoline system with multifilament main lines of about $50 \mathrm{~km}$ in length, and 9-11 branch lines with 1500-2000 hooks that fish at $90-350 \mathrm{~m}$ depth. They use frozen milkfish, Sardinella spp., Decapterus spp. and squid as baits.

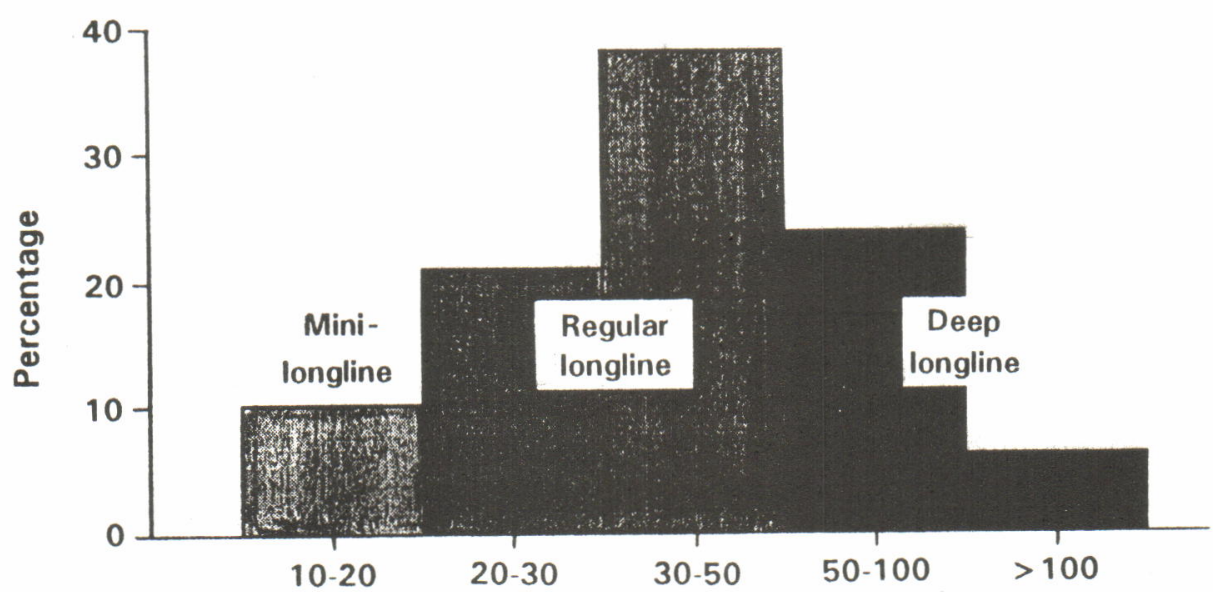

Figure 4. Classification of 251 boats surveyed in the Port of Benoa in 1992 by vessel type and size (tones)

\section{- Processing and export}

There are four processors at Benoa which prepare iced tuna for export. The largest is PT. Sari Segara Utama, followed by PT. Perikanan Samodra Besar, PT. Hemakaruna Citra Bali and PT. Bali Nusa. The tuna are gutted and gilled 
Davis, T.; Bahar, S. and Farley, J.

at sea and stored on ice. The largest proportion of tuna are semi-dressed for export to Japan, which involves removing fins but leaving the tail stock intact. They are packed in plastic and foam-lined cardboard cartons which are kept chilled with blocks of dry ice. They are exported with the head removed to Hawaii, California, Singapore and Hong Kong, and as loins to France. These are exported through the Ngurah Rai Airport at Denpasar. There has been a marked increase in the proportion of fresh to frozen tuna exported since 1990 (Table 2). A small proportion of tuna not suitable for export is consumed locally in Bali. Though most of the retained tuna is canned either in Bali or East Java.

\section{Performance of the Bali Longline Fishery Activities}

\section{- Species composition}

A total of 957 vessel landings and 4050 tonnes of fish were processed at PSB in 1993 (Table 3a). Yellowfin tuna was the most abundant species landed $(57.2 \%$ of total landings by weight) followed by bigeye tuna $(31.3 \%)$, albacore $(3.8 \%)$, billfish $(3.6 \%)$, southern bluefin tuna $(3.1 \%)$ and others (mainly sharks) $(0.9 \%)$. The company exported 2726 tonnes of fish, of which 81.2 tonnes (3\%) were southern bluefin tuna (SBT). The average dressed weight of fish (calculated from Tables $3 \mathrm{a}$ and $3 \mathrm{~b}$ ) was highest for SBT $(103.4 \mathrm{~kg})$, then billfish $(58.8 \mathrm{~kg})$, yellowfin tuna $(38.4 \mathrm{~kg})$ and albacore $(21.1 \mathrm{~kg})$. The average price per kilogram for whole tuna "free on board" (price landed in Benoa) paid by exporters buying at PSB in 1993 was SBT (US\$5.7), bigeye tuna (US\$5.2), and yellowfin tuna (US\$4.2). A total of 16711.4 tonnes of tuna was exported from Bali Province, in 1993 (Table 2).

Assuming that the proportion of SBT exported by PSB was representative of the proportion exported by other processors, then about 498 tonnes of SBT were exported in 1993. Using the ratio (calculated from Table $3 \mathrm{a}$ and c) of exported to total SBT processed by PSB (81.241/124.87 tonnes) and extrapolating that to all processors gives an estimated total landing of SBT at Benoa of 765 tonnes. Using the ratio of exported to total tuna processed by PSB (2 $726.1 / 4050$ tonnes) the total longline catch of tuna landed in Bali was 24800 tonnes in 1993. This is a significant component of the estimated global catch of 13750 tonnes SB'T (Klaer et al. 1994), particularly as it consists entirely of spawning fish. Whether the species composition and proportion of exportable tuna processed by PSB are representative of other companies will be examined in the future subsampling landings at PT. Sari Segara Utama, the largest processor in Bali. 


\section{- Seasonal catch composition}

The seasonal distribution of catches by month for each species of tuna and billfish is presented in Figure 5. The total catch was fairly consistent throughout the year except for February and, to a lesser extent, March and April. Catches were low and there were fewer landings (Table 3a) in February than in other months due to the peak of the western monsoon. SBT catches showed marked seasonality in contrast to catches of yellowfin tuna (YFT), bigeye tuna (BET) and billfish. The largest catch of SBT was in January and there were negligible catches from May to August. Albacore catches also varied seasonally, being highest from May to September, when the water was cooler.

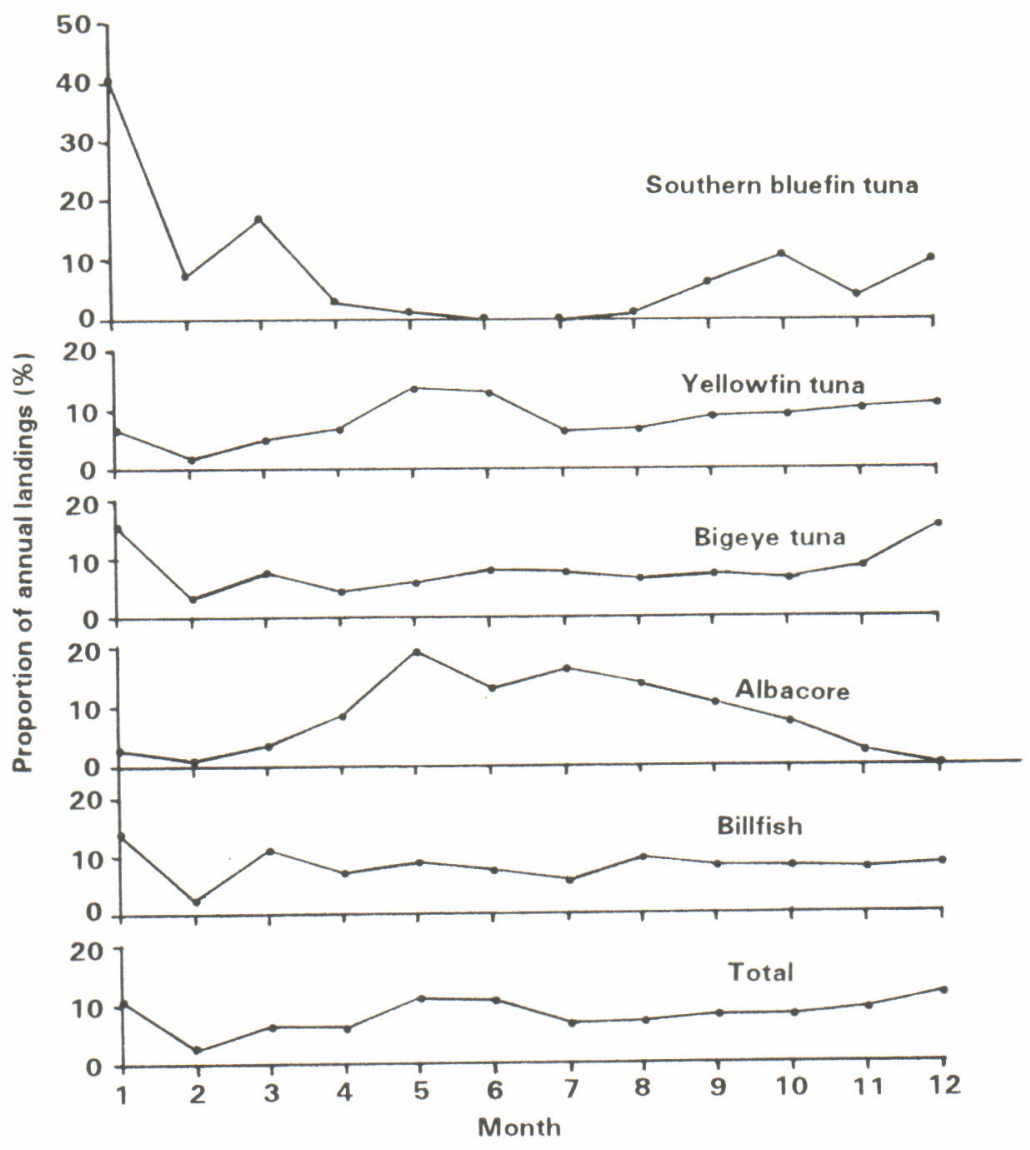

Figure 5. Seasonal distribution of catch by month for each species and total catch expressed as a percentage of the annual catch. 
Davis, T.; Bahar, S. and Farley, J.

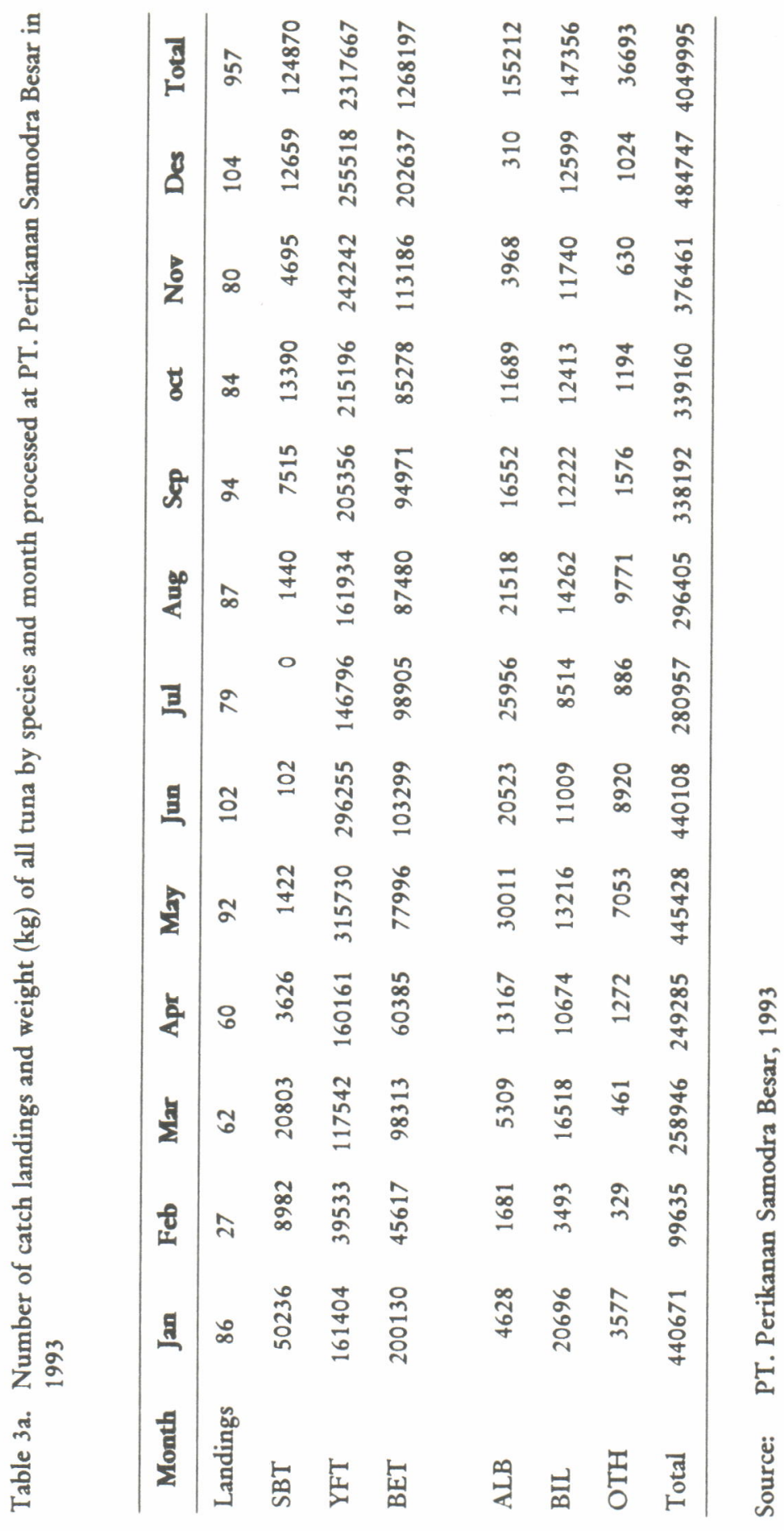




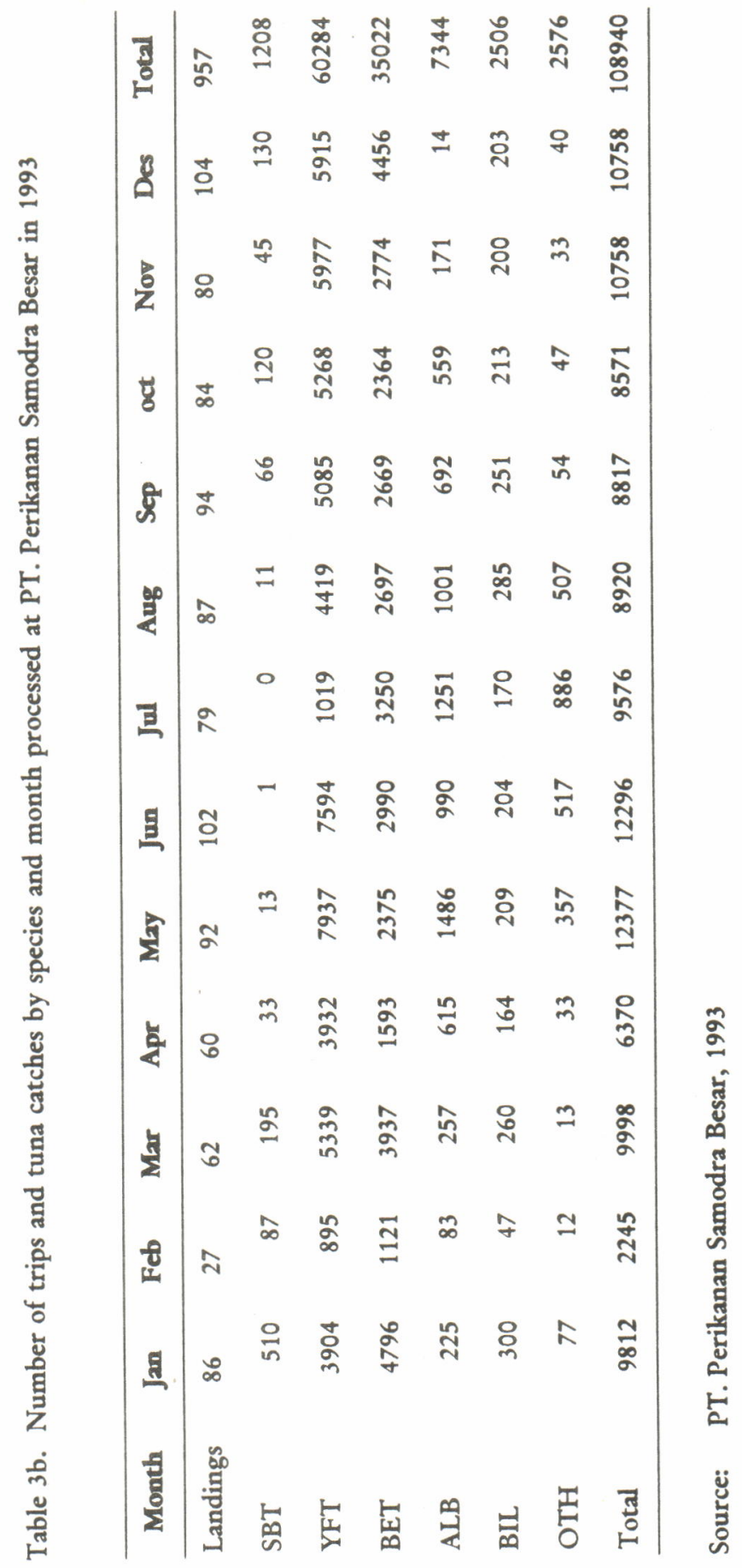


Davis, T.; Babar, S. and Farley, J.

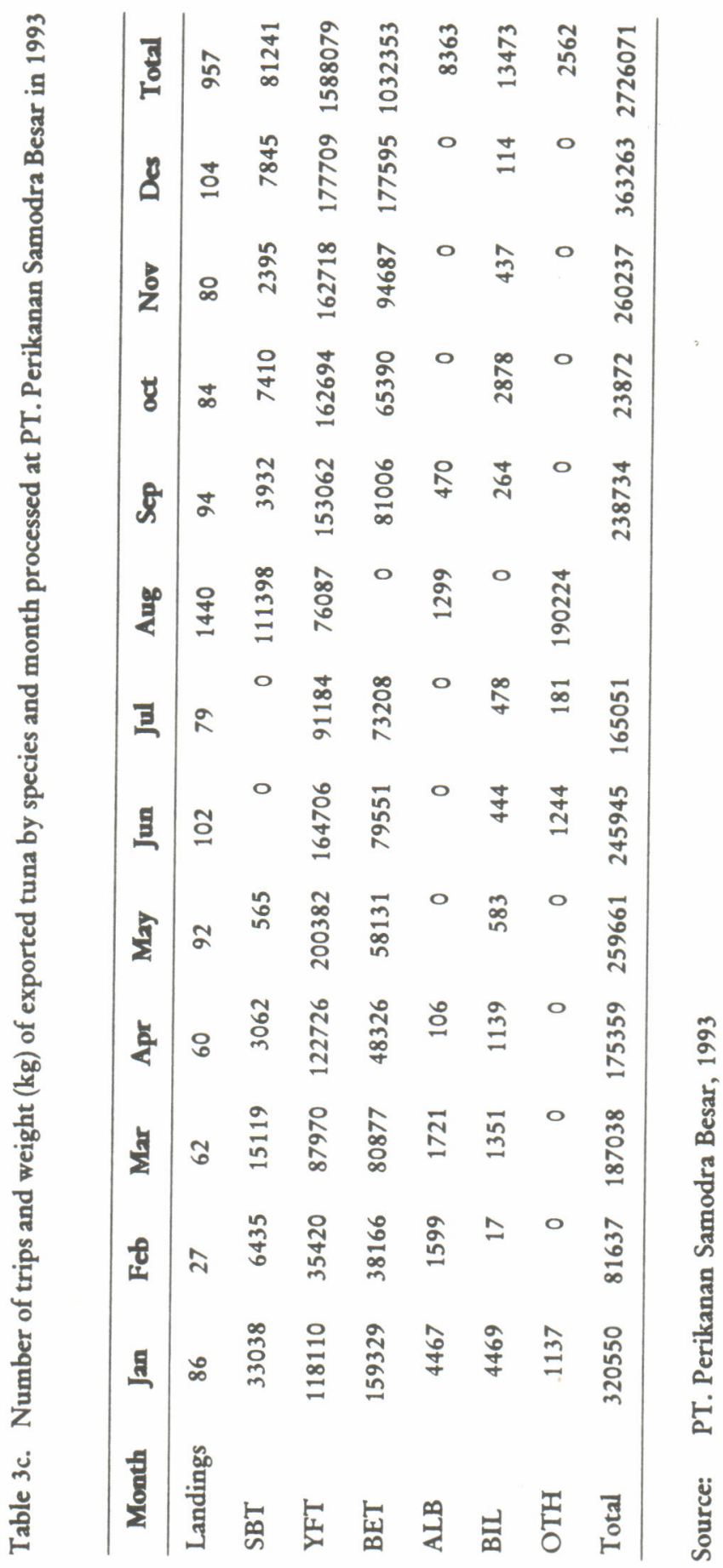


SBT remain a small component $(3.1 \%)$ of the total longline catch in Bali. It is unlikely that the proportion of SBT caught will increase in the future. In recent years, there has been a trend away from live bait towards more profitable deeper sets with frozen baits, which target BET and also catch the large YFT. SBT, which is the highest valued species, appears to be caught more readily in shallow sets, but is a small component of a catch dominated by the lower-valued, small YFT.

\section{Biological Aspects of Southern bluefin tuna (SB'T)}

A total of 1208 SBT were processed at PSB in 1993. Lengths ranged from $164-199 \mathrm{~cm}$ (mean of $187 \mathrm{~cm}$ ). The length-frequency distribution was skewed, with a peak abundance in the 191-195 cm length class (Figure 6). The dressed weight of SBT ranged from 55 to $170 \mathrm{~kg}$ (mean of $103 \mathrm{~kg}$ ). Most fish were in the 76-125 kg weight class (Figure 6). The weight/length plot of these fish shows a somewhat scattered relationship due either to differences in condition or, possibly errors in the length measurement (Figure 7). Least-squares regressions fitted to these data provided the following equations:

$$
\begin{aligned}
& \mathrm{W}=0.000000078 \mathrm{~L}^{4.012}, \mathrm{df}=1,897, \mathrm{p}<0.001, \\
& \text { where } \mathrm{W}=\text { weight }(\mathrm{kg}) \text { and } \mathrm{L}=\text { length }(\mathrm{cm}) .
\end{aligned}
$$

The fitted line is somewhat lower than that given in Warashina and Hisada's (1970) data for pre- and post-spawning SBT, indicating that in the northern part of the spawning ground condition is lower than elsewhere. The length and weight data were examined for seasonal trends. Length showed little change between January and June which is near the end of the 1992/93 spawning season (Figure 8). Largest speciemens were caughtin August, with smaller fish spawning more common late in the year. More intensive sampling is required to determined whether this trend is significant. August appeared to be the start of the 1993/94 spawning season. Seasonal changes in the weight of southern bluefin tuna matched those of length. Condition calculated as the observed weight divided by the weight predicted from the weight/length relationship showed no discernible trend. Condition in April and August was markedly higher than in other months, but the difference may have been due to small sample sizes. Ovary weight expressed as a percent of body weight showed no trends over the sampling period (Figure 9). Throughout the sampling period, ovary weight generally exceeded $2 \%$ of body weight.

The capture of southern bluefin tuna at the surface may be linked to their spawning activity rather than be a preference for feeding in warm shallow. It is likely that they spawn at the surface like their northern hemisphere counterparts, the northern bluefin tuna. Their larvae are found in the surface 
Davis, T.; Bahar, S. and Farley, J.
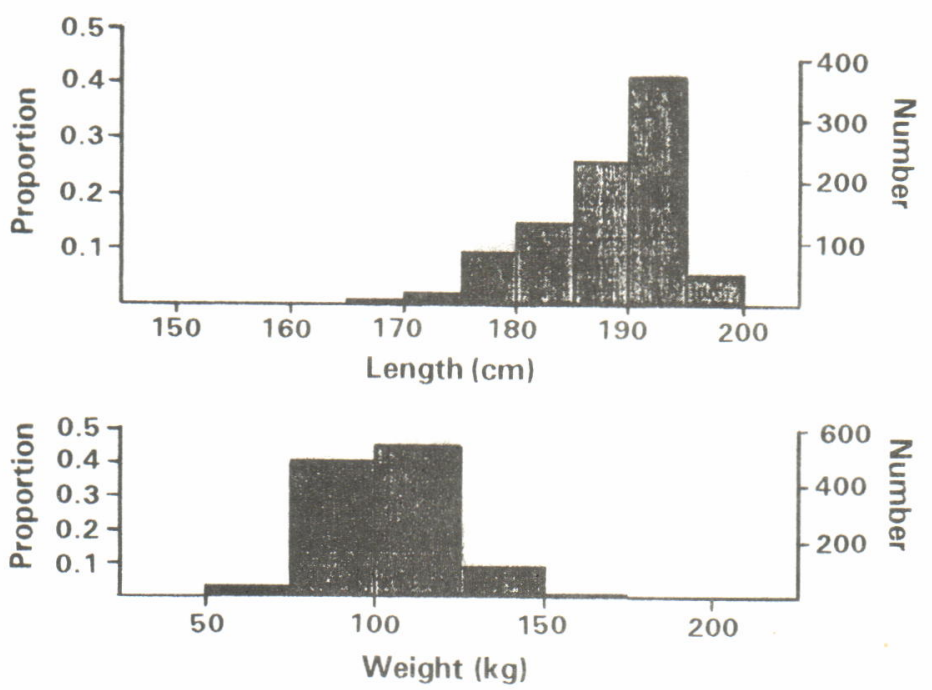

Figure 6. Length and weight frequency-distribution of southern bluefin tuna processed at Pt. Perikanan Samodra Besar in 1993. The numbers and proportions of fish in $10 \mathrm{~cm}$ length and $25 \mathrm{~kg}$ weight classes are shown.

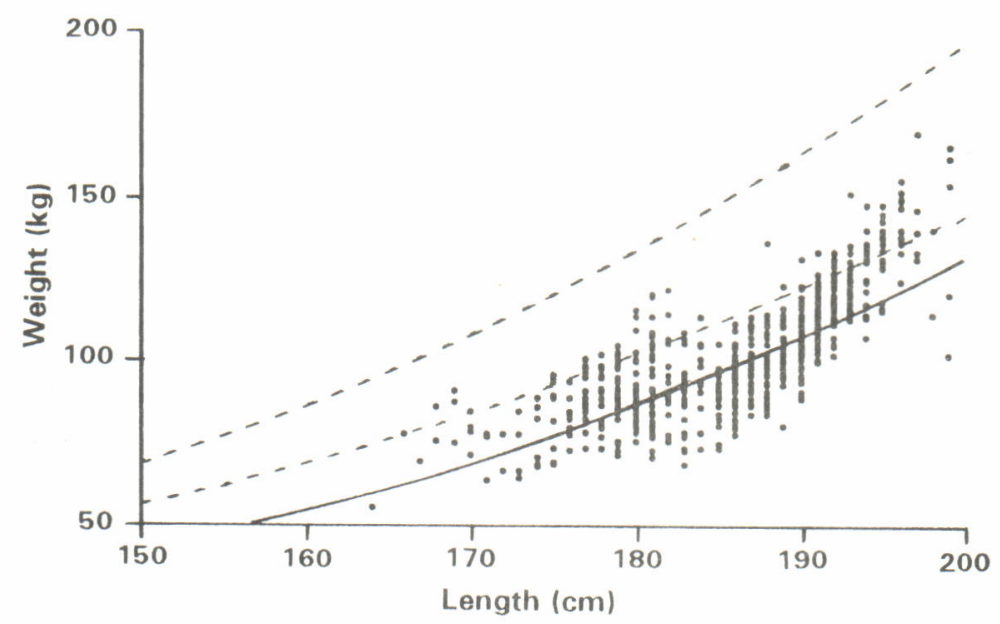

Figure 7. Weight/length relationship of dressed southern bluefin tuna landed at Pt. Perikanan Samodra Besar in 1993. The solid line is the regression line fitted to these data. The upper and lower dotted lines represent the gilled and gutted weights of warashina and hisada (1970) for pre-spawning and post-spawning southern bluefin tuna $>130 \mathrm{~cm}$ length 

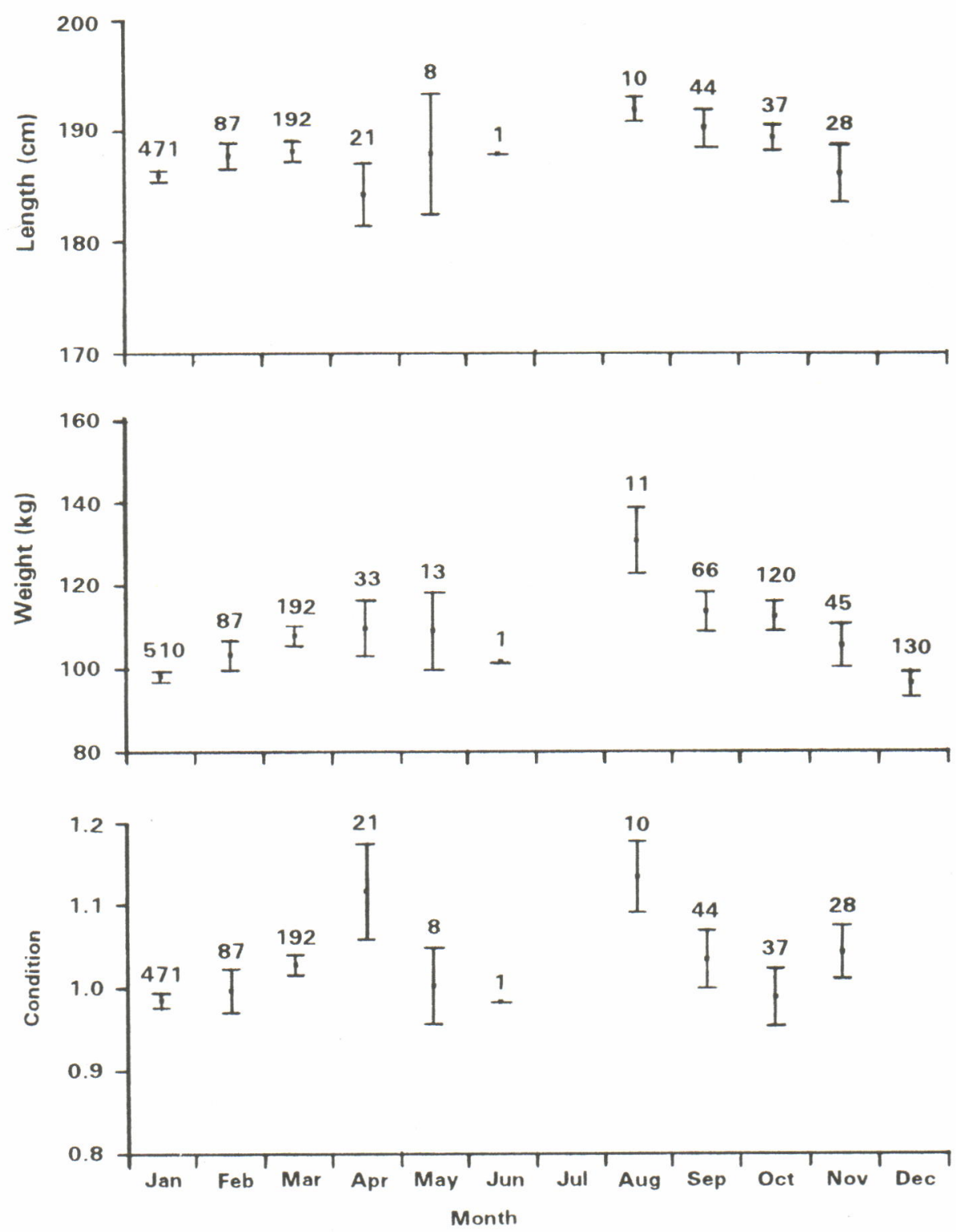

Figure 8. Length, weight and condition (observed/predicted weight) of southern bluefin tuna landed at Pt. Perikanan Samodra Besar each month in 1993. Means and $+/$-standard errors of the mean are shown. 
Davis, T.; Bahar, S. and Farley, J.

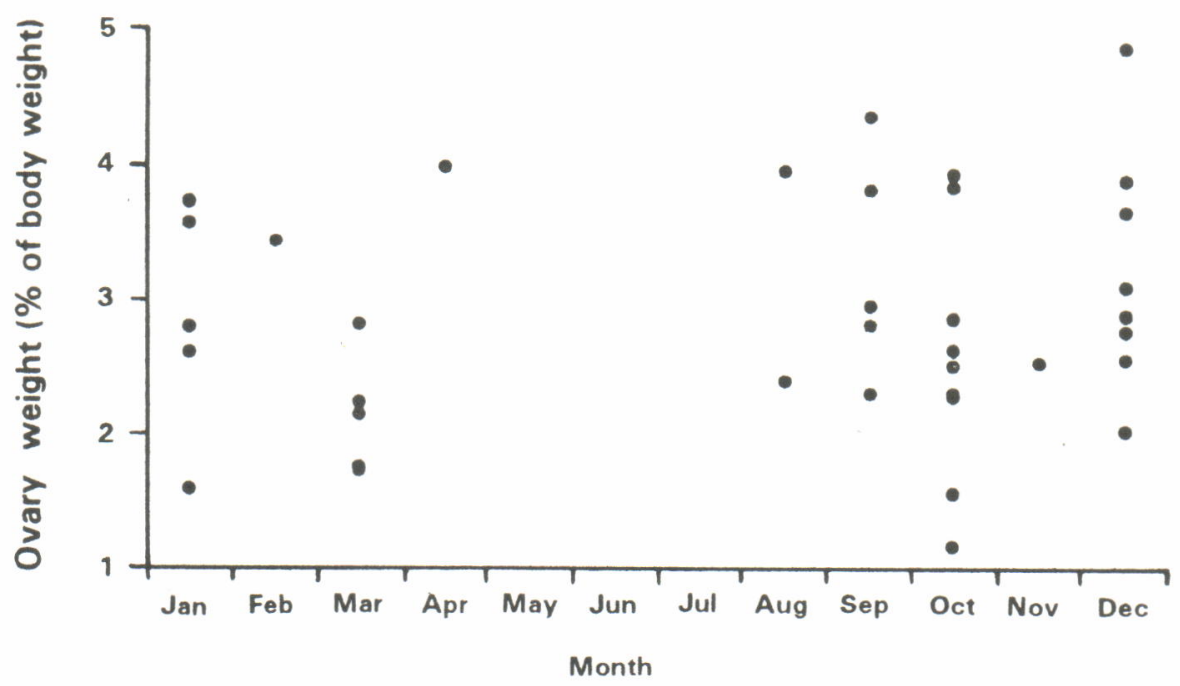

Figure 9. Ovary weight of southern bluefin tuna expressed as a percent of body weight collected each month during 1993 .

mixed layer (Davis et al. 1990). The warm shallow water in the tropics is not their preferred habitat for feeding. Bluefin tuna have the most temperate distribution of all tunas, having evolved a highly specialised blood vascular system that enables them to maintain elevated body temperature while feeding in cold water (Holland et al. 1992). In Tasmanian waters, southern bluefin tuna are targeted by longlines fished at depths of $40-160 \mathrm{~m}$ and sea surface temperature of $10-12^{\circ} \mathrm{C}$ (Cropp 1994). Despite being adapted to feed in cold water as adults, their early life is spent, like all Thunnus spp., in tropical and subtropical waters (Nishikawa et al. 1985).

The seasonal distribution of the catch of southern bluefin tuna is probably related to the duration of their spawning season. The heavy ovaries in all months that southern bluefin tuna are caught in the region is evidence that they spawn throughout this period (August to April). The largest catches were in January which would suggest that this is the month of highest spawning activity. As ovary weight did not decline late in the year, the same individuals probably do not remain on the spawning ground for the whole season: they may spawn and then return to temperate waters. Only spawning fish would be on the grounds. This aspect requires further, more detailed study. The maintenance of condition through the spawning season supports the theory that fish that have lost condition through spawning leave the ground and are replaced by fresh fish. 
Only southern bluefin tuna larger than $163 \mathrm{~cm}$ have so far been measured during monitoring of this fishery. This is larger than the minimum size at first maturity of about $150 \mathrm{~cm}$ determined from examination of the ovaries of fish caught in the Indian Ocean south of the spawning grounds (Davis 1994). Possibly the criteria used to assess maturity (ovary weight and oocyte diameter) of these fish caught further south reflects their potential to spawn and that some of the smaller, less mature, fish do not actually spawn that season. Alternatively, it is possible that only the older, larger fish reach the northern part of the spawning ground that is the focus of the Benoa-based longline fishery.

\section{Acknowledgements}

We wish to thank the Branch Head of PT. Perikanan Samodra Besar Benoa, Mr. S. Simorangkir, for facilitating catch sampling at the processing plant and providing historical fishing records of the company. The Provincial Fisheries Service of Bali provided statistics on the tuna exported from Ngurah Rai Airport. We are grateful to Mr Labuhan Siregar and Mr Mashar Machmud for monitoring the tuna catches at PT. Perikanan Samodra Besar and thank the masters of fishing vessels who voluntarily collected ovaries of southern bluefin tuna during their fishing operations. We thank Dr T. Polacheck and Mr J. Gunn for reviewing the manuscript and Dr. V. Mawson for editorial improvements. This research was supported by Fisheries Resources Research Fund grant 92/93/45 from the Australian Fisheries Management Authority.

\section{References}

Anon. 1994. Report of the thirteenth meeting of Australian, Japanese and New Zealand scientists on southern bluefin tuna. Report to management. 20-29 April 1994, Wellington, New Zealand. 13 pp.

Caton, A., K. Mc Loughlin, and M.J. Williams. 1990. Southern bluefin tuna; Scientific background to the debate. Bureau of Rural Resources Bulletin 3, 41 pp. Australian Government Publishing Service, Canberra.

Cropp, D.A. 1994. Summary of AFZ observer program cruise reports: Japanese style tuna longline fishing in the Australian fishing zone. Australian Fisheries Management Authority Report AA94(1), 33 pp.

Davis, T.L.O., G.P.Jenkins, and J.W. Young. 1990. Diel patterns of vertical distribution in larvae of southern bluefin, Thunnus maccoyiii and other tuna in the East Indian Ocean. Mar. Ecol. Prog. Ser. 59: 63-74.

Davis, T.L.O. 1994. Size at first maturity of southern bluefin tuna based on RTMP and AFZ observer sampling. 13th SBT Trilateral Scientific Meeting. 19-29 April 1994, Wellington, New Zealand. SBFWS/94/5. 
Davis, T.; Bahar, S. and Farley, J.

Holland, K.N., R.K. Brill, K.C. Chang, J.R. Sibert, and D.A. Fournier. 1992. Physiological and behavioural thermoregulation in bigeye tuna (Thunnus obesus). Nature 358: 410-412.

Klaer, N., T. Polacheck, and K. Sainsbury. 1994. Southern bluefin tuna stock and recruitment projections. $13^{\text {th }}$ SBT Trilateral Scientific Meeting. 19-29 April 1994, Wellington, New Zealand. SBFWS/94/15.

Nishikawa, Y., M. Honma, S. Ueyanagi, and S. Kikawa. 1985. Average distribution of larvae of oceanic scombroid fishes, 1956-1981. Contrib. Far Seas Fish. Res. Lab., Fish. Agency Jpn. 236: 1-99.

Warashina, I. and K. Hisada. 1970. Spawning activity and discoloration of meat and loss of weight in the southern bluefin tuna. Bull. Far Seas Fish. Res. Lab. 3: 147-166. 